\title{
UNLOCKING CREATIVE MINDS TO ENGAGE SDGS THROUGH DESIGN EDUCATION IN JAPANESE HIGH SCHOOL EDUCATION
}

\author{
Wei Leong, Leon LOH, Moe SHIMOMURA and Yanfang ZHANG \\ Kyushu University, Faculty of Design, Japan
}

\begin{abstract}
This study aimed to clarify the use of a pilot design programme as a form of general education in the Japanese high school education to enhance awareness of Sustainable Development Goals (SDGs) and develop $21^{\text {st }}$ Century competencies (21CC) and social-emotional learning (SEL). The challenge for this study is to integrate design education in a high education system that has no structure for design learning. Based on a questionnaire survey, the pilot design programme allowed 17 high school participants with no design experience to solve authentic problems through design. Besides, design activities promote the development of 21CC and SEL. As a form of education for sustainable development (ESD), the current study has the potential to enhance awareness of SDGs and sustainable issues.
\end{abstract}

\section{Keywords: Design education, SDGs, $21^{\text {st }}$ Century competencies, social emotional learning}

\section{INTRODUCTION}

Students in the $21^{\text {st }}$ Century face a complex and uncertain future that includes challenges defined within the SDGs. Amid global developments on sustainability issues, new directions set for Japanese high school education will see an increase in emphasis on education that promotes three key educational objectives such as, 1) social and community connectedness; 2) the development of thinking skills, decision-making skills and expression skills; and 3) enhance moral education and experiential learning. Design education may be well placed to achieve the three vital educational objectives mentioned above. Design education as a form of general education at the secondary and senior secondary level can often be associated with Design and Technology (D\&T) and Technology education (TE) where design learning can often be found in the subjects. However, in Japan, design education is mainly available in tertiary education. Although TE is offered in Japanese junior high schools, under the current national syllabus, the subject focuses mostly on technological knowledge and skills with almost no elements of design learning activities, as compared to overseas.

With no structures in place to adopt design as a form of learning in current Japanese high school education, the current study is part of a larger study to propose design programmes that can be integrated into main-stream general education. The key objective is to achieve the three key educational objectives for Japanese high school education through the development of 1) SDGs awareness; 2) 21CC, and 3) SEL. Besides, the current study can draw on the key essence of design learning in general education based on established subjects like D\&T and TE while not duplicating the subject into Japanese high school education. The objective of current research is to clarify the effectiveness of a pilot design programme developed for high school students to increase SDGs awareness, and develop 21CC and SEL through design activities.

\section{LITERATURE REVIEW}

\subsection{Essence of design education in general education}

The common established concepts about design education have been related to specialist education to develop students as design professionals, as explained by Nigel Cross [1]. Cross went on to provide three main areas of justifications based on designerly ways of knowing to justify the values for design as general education for everyone. Cross also explained that through design, students could be developed to solve ill-defined problems which are different from well-defined problems commonly found in 
sciences and humanities. In a way, designing is a form of problem-solving that tackle real-world problems, which are typically ill-defined, but not all problem-solving activities involve designing [2][3]. Tackling real-world problems through design can be commonly found in learning activities for subjects such as D\&T and TE. Though originating from craft education, D\&T and TE have moved away from craft education, and design activities have gradually increased in the subject to develop 21CC [4]. As a form of general education, D\&T and TE can be found in Europe, America, Oceania and Asia. But the educational focus of the subjects generally differed among countries based on factors such as political, social, school and individual context [5[6][7][8][9].

In D\&T and TE, though students are exposed to design areas such as communication design, product design, textile/fashion and etc., but as general education, the subject focus on a non-vocational approach where student achievements in the design process are more important than the final output, such as prototypes or artefacts [10]. The focus on the process rather than the outcome can be further explained by the assessment methods [11]. Drawing from the perspectives of D\&T and TE in various studies, the key essence of design learning for general education may be presented as follow.

- Learning through design activities to develop higher-order thinking skills such as critical thinking, creative thinking, system thinking and problem-solving skills [12][13][14][15][16]. Also, students may develop the ability to plan, execute and evaluate [17].

- Promoting sociocultural learning through discussions and conversations [18].

- Solving ill-defined real-world problems reinforce learning of other subjects in the curriculum, such as natural science, mathematics and computer science. Besides, solving authentic problems connect knowledge and skills to real-world application. As such, developing SEL skills through making connections between problems and needs [19][20].

- Student-centred constructivist approach towards learning [21].

Although it should be reminded that the current study does not aim to re-create D\&T or TE education in Japanese high school education, the key essence extracted from the literature reviews will set the direction and approach in conceptualising the pilot design programme for this study.

\section{RESEARCH METHODOLOGY}

This study sought to answer the research questions as follow, i) Does the programme in current study increase student's awareness of SDGs?; ii) Does the programme in current study increase student's awareness of possible SDGs related issues in their community?; and iii) Does the programme in the current study help to develop 21CC and SEL?

\subsection{Research approach and method}

The current study employed a qualitative research approach where case study method is used as an educational tool for understanding pedagogical processes as described by Aaltio and Heilmann [22]. In the case study approach, research strategies from quantitative and qualitative methods can be brought together [23]. The current study was conducted at Fukusho High School in Fukuoka city, Japan. The considerations for selecting Fukusho High School as target school was based on the following: a) school is a typical public high school, b) consist of mix student academic abilities and c) supportive teachers who are willing to explore the use of design education as a form of learning for high school students.

\subsection{Participants, research design and implementation}

After a series of discussions done with the teachers to understand the student profile and the school objectives, the pilot design programme was decided to be implemented as part of the Global Management Programme. The Global Management Programme is an entrepreneurship programme offered by the school to develop students with abilities to solving real-world problems, develop broad perspectives, analytical skills, communication skills and management skills. The structure of this programme is flexible to accommodate a variety of learning experience. This provided a good opportunity for the pilot design programme to be fitted into the Global Management Programme while still achieving the school objectives.

The participants of this study were 17 first-year students (about 16-year-old) who had no prior experience in designing. The content of the pilot design programme was first proposed by the authors but subsequently co-developed with teachers to achieve the objectives of the school. Due to the time constraint of the school, the pilot design programme was planned to be conducted over four sessions. Each session consisted of 50 minutes. The key objective of the pilot programme was to allow students 
to tackle SDGs issues by design. The key student outcome was to increase students' awareness of the SDGs, and confidence in contributing to SDGs as an individual.

Based on the literature review, the pilot design programme was conceptualised to contain key learning features where students engaged in solving real-world design problems and design activities that focused on the process of designing rather than the final output. During the process of designing, thinking skills, communication skills and SEL would be developed. In addition, SDGs themes such as Waste and Climatic Changes were chosen to set the context of solving real-world design problems, and the scope of problems was constrained within the students' community. This was also to provide students with opportunities to develop social and community connectedness. The pilot programme was facilitated by one of the teachers-in-charge in the Global Management Programme who happened to be an art teacher and was familiar with the design process. The programme concept and implementation schedule can be presented in Figure 1. More details about the programme implementation can be found on the authors' website [24]. The primary set of data collected for this study came from students' feedback about the programme using a questionnaire survey. The survey was conducted after the completion of the pilot programme. The detailed outline of the questionnaire survey, which includes the key focus of each part, the content of the questions and question types can be presented in Table 1.

\section{SDGsと関係がある地域課題の発見}

(Finding Community Issues)
デザイン思考で課題を解決

(Design Thinking Approach)

\section{学生が得られる効果}

\section{(Student Outcomes)}

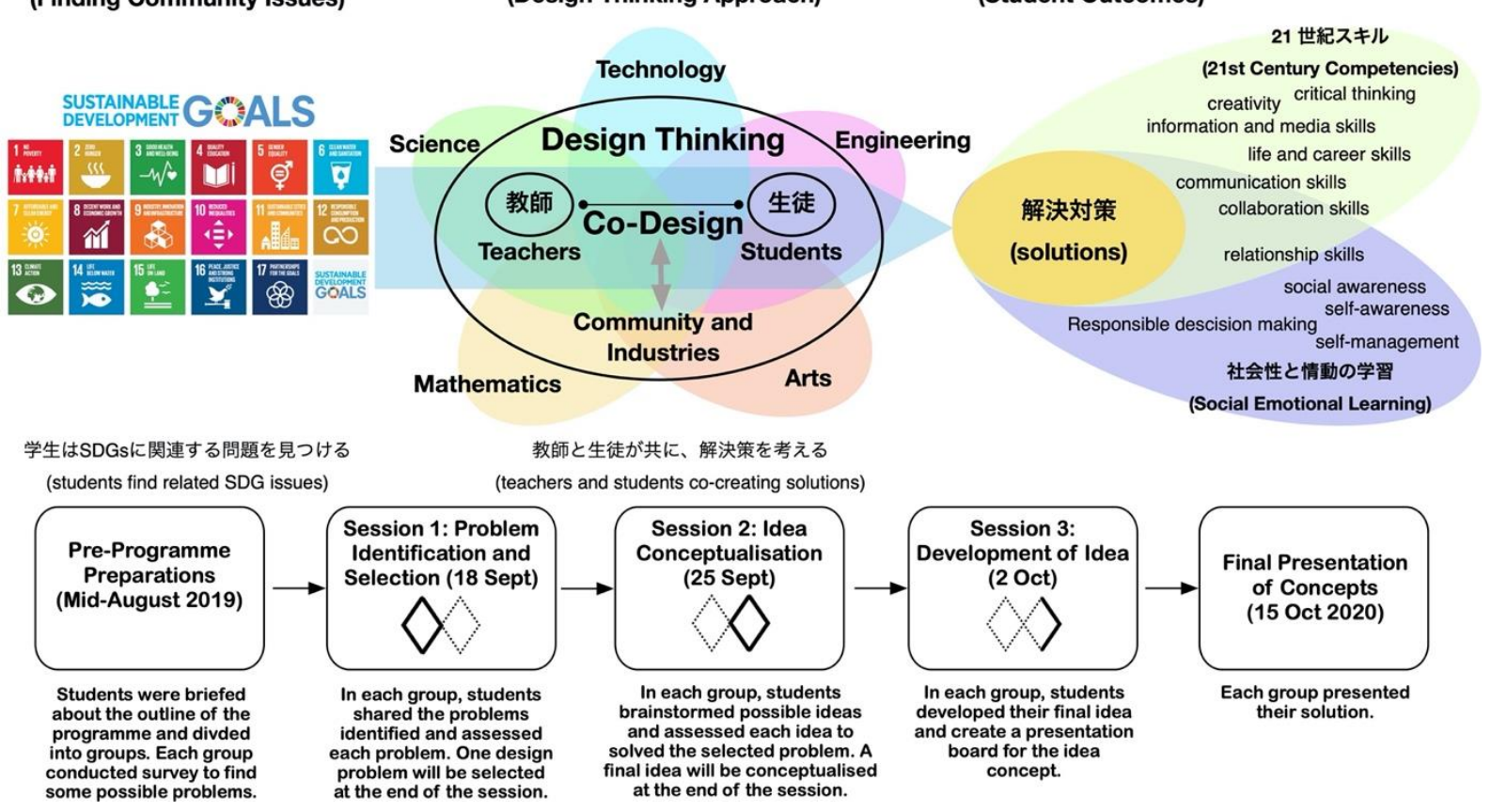

学生はSDGsに関連する問題を見つける (students find related SDG issues)

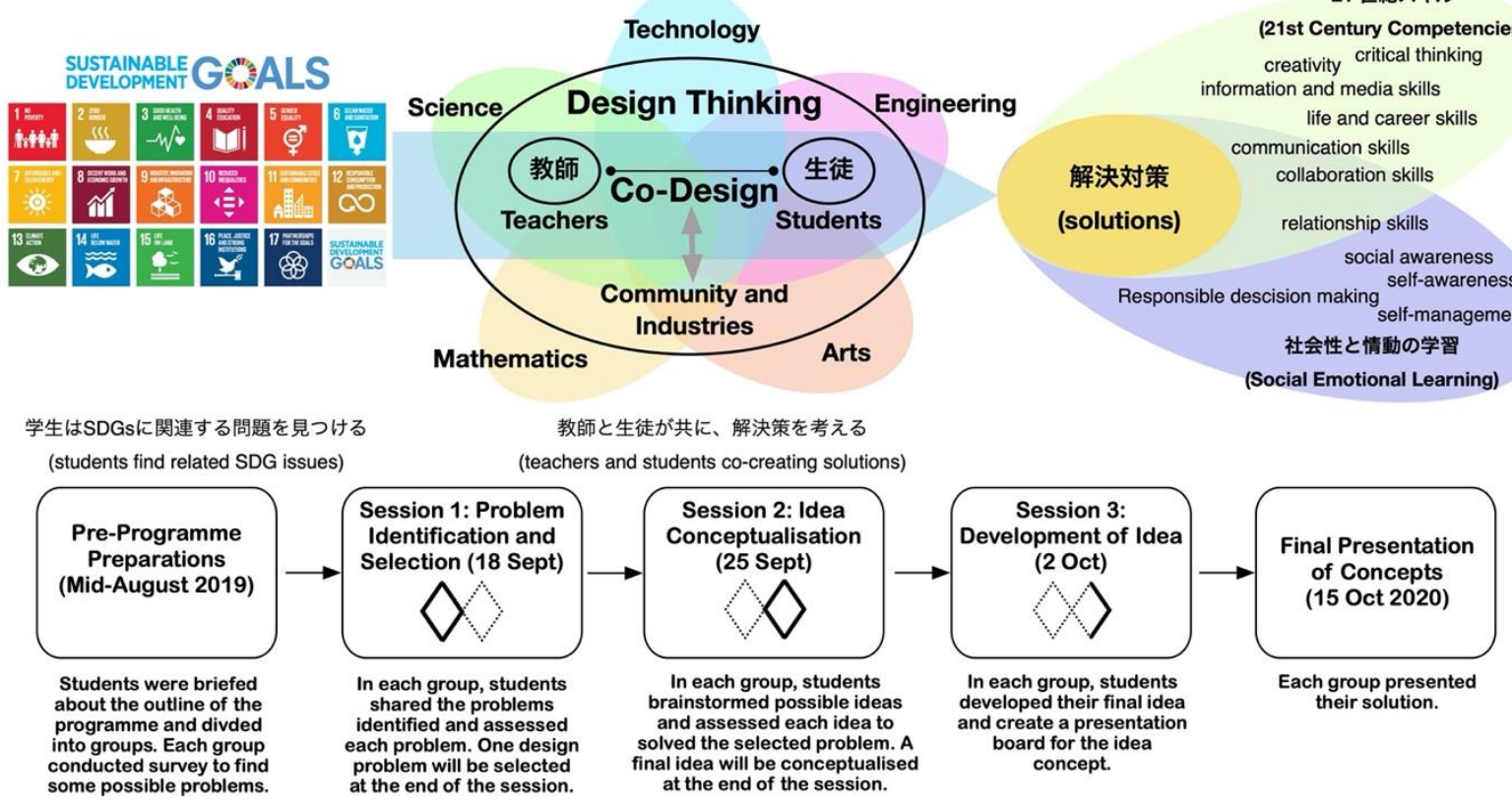

Figure 1. Concept of pilot design programme and programme schedule

Table 1. Question items in each part of the questionnaire survey

\begin{tabular}{|c|c|c|}
\hline Key Focus & Questionnaire Survey Items (Question Type is written in the brackets) & Question Type \\
\hline $\begin{array}{l}\text { Part One: Awareness of } \\
\text { SDGs and Sustainability } \\
\text { Issues }\end{array}$ & $\begin{array}{l}\text { Q1. My awareness of Sustainable Development Goals (SDGs) increased after this } \\
\text { workshop. } \\
\text { Q2. This workshop provides me with the opportunity to know about sustainable } \\
\text { issues in around me } \\
\text { Q3. I am more aware of the sustainable issues around my residential community } \\
\text { after this workshop. } \\
\text { Q4. (a) I believe I have the ability to contribute to the SDGs in my own capacity. } \\
\text { (b) Please provide a reason for your respond for Q4. }\end{array}$ & $\begin{array}{l}\text { Q1 to Q4 (a): Closed-ended. } \\
\text { Scale of } 1 \text { to } 5 \text { with } 1 \text { being } \\
\text { strongly disagree and } 5 \text { being } \\
\text { strongly agree) } \\
\text { Q4(b): Open-ended }\end{array}$ \\
\hline $\begin{array}{l}\text { Part Two: } 21 C C \text { and SEL } \\
\text { Development }\end{array}$ & $\begin{array}{l}\text { Q1. This workshop enhanced my communication skills with my teammates. } \\
\text { Q2. This workshop allows me to think of new ideas to solve real world problems. } \\
\text { Q3. This workshop teaches me to listen to my other points of views. } \\
\text { Q4. This workshop teaches me how to evaluate my ideas. } \\
\text { Q5. This workshop shows me that I can play a part to contribute to the sustainability } \\
\text { of my society and environment. }\end{array}$ & $\begin{array}{l}\text { Q1 to Q5: Closed-ended. } \\
\text { Scale of } 1 \text { to } 5 \text { with } 1 \text { being } \\
\text { strongly disagree and } 5 \text { being } \\
\text { strongly agree) }\end{array}$ \\
\hline $\begin{array}{l}\text { Part Three: Further } \\
\text { Improvements and } \\
\text { Reflections }\end{array}$ & $\begin{array}{l}\text { Q1. What are some areas for improvement for this workshop? } \\
\text { Q2. What do I think about this workshop? }\end{array}$ & Q1 \& Q2: Open-ended \\
\hline
\end{tabular}




\section{FINDINGS}

The responses for Part One and Two of the survey can be presented in Figure 2 and Table 2. Based on Part One of the survey, most of the students agreed that the workshop had increased their awareness of SDGs. The opportunity to find real-life problems in the programme also allowed students to gain more awareness of environmental sustainability issues within their community. Through this programme, many students realised that they could contribute to the SDGs within their means.

Based on Part Two of the survey, the design-based activities in this programme provided students with the opportunity to enhance their communication skills with others and at the same time, taught them how to listen to other points of view. In terms of divergent and convergent thinking skills, students felt that they were able to generate ideas for the problems, and then evaluate and narrow down their ideas to the most suitable solution.

As a reflection on the workshop, the key common responses in Part Three of the survey can be presented in Table 3. Responses from students further showed that the programme provided them with positive learning experience such as increased sensitivity to environmental sustainability issues, engaged in solving design problems and required them to seek different perspectives during solution-finding. On the other hand, students think that the duration for each session was too short for deep discussions and creative ideation. Besides, thinking time was considered short due to the time constraint.
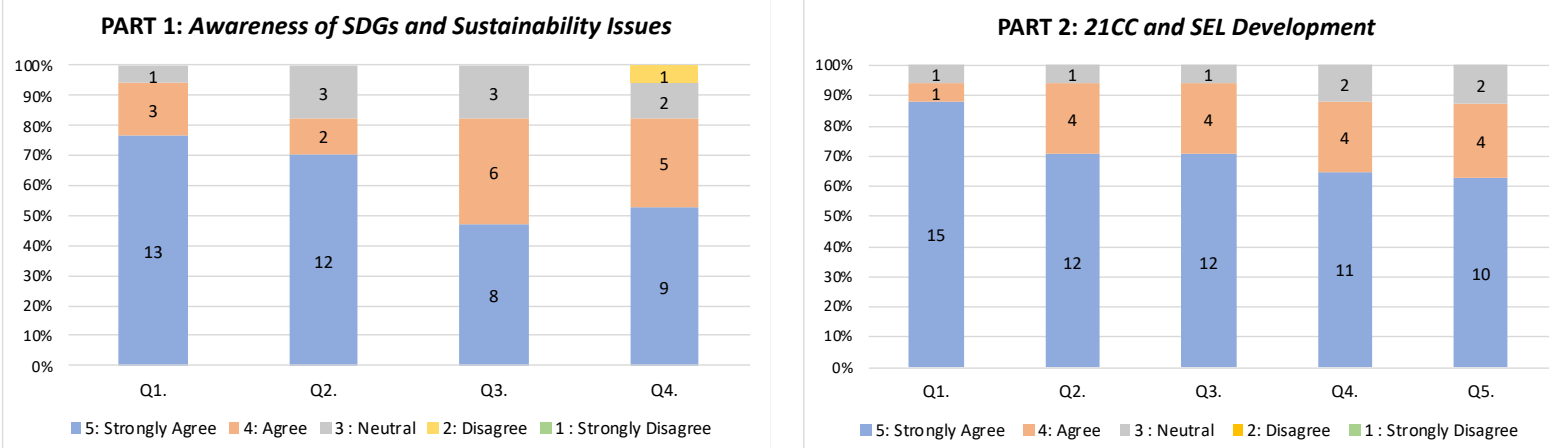

Figure 2. Responses for Part 1 and 2 of the questionnaire surveys

Table 2. Key common responses to students' self-capabilities to contribute to SDGs

Common Key Responses to the Open-Ended part of Q4 in Part 1 of the Questionnaire Survey

Students believed that they can apply the ideas in situations that they are familiar with and in places closer to themselves.

Students may be able to take actions within their own abilities such as, waste separation, stop littering, stop using plastic bags during shopping, etc.

There are still many things that students believe they do not know.

Students have gain more understand of SDGs after the programme, thus contributing to SDGs issues are possible. Perhaps as an individual it would be difficult, but in a group, contributing to SDGs may be possible.

Student felts that they are able to come out with different ideas to solve sustainability issues after this programme.

Students have gained more awareness to issues such as waste and climatic changes through this programme. They can now be more active to think about solving such issues.

Table 3. Key common responses to open-ended reflections

Common Key Responses to Part 3 of the Questionnaire Survey

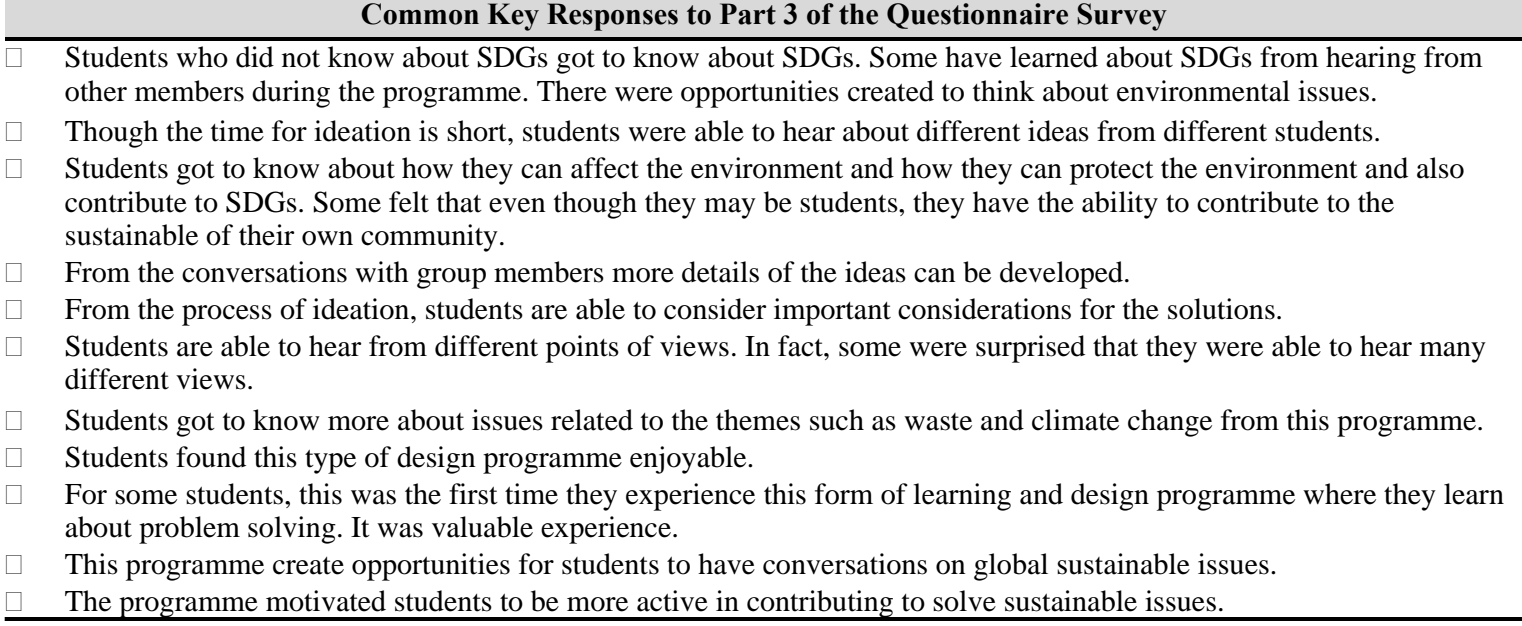




\section{DISCUSSIONS AND LIMITATIONS}

As a pilot programme, the feedback from the students provided several crucial implications for further development of subsequent design programmes and at the same time reflect on how the new educational directions for Japanese high school education may be achieved through design education. Firstly, design education as a form of general education can be a promising form of problem-based learning (PBL) for high school students. Although PBL often involved solving real-world problems, PBL does not necessarily need to include the process of design. In other words, PBL can be applied to the study of traditional academic subjects such as languages, sciences, humanities, etc. that do not necessary involved any process of design. But on the other hand, design learning can be a form of PBL. Thus, to integrate design learning into an educational system that has no design education, it may be necessary to position design education as an existing common form of learning such as PBL. Design learning may then be to better integrate into the existing Japanese high school education structure. The current pilot programme may provide useful insights for design researchers who are involved in future studies to incorporate design education as general education in the Japanese high school. This research may also give the international community to understand the challenges and possibilities of implementing design education into an education system with no existing structures for design education.

Secondly, through design activities, it was clear that students experienced and gained important 21CC and SEL such as critical thinking, collaboration skills, communication skills and considering different points of view that leads to empathy. At the same time, engaging in authentic problems allowed students to understand issues related to their community better and generated social awareness and responsibilities. Besides, design activities may engage students in ethical reasoning process to think about the implications and consequences of individual actions that impact the community.

Thirdly, as a form of education for sustainable development (ESD), the current study showed potential that design activities can enhance students' understanding of SDGs and issues related to SDGs through authentic problems. Authentic problems seemed to help students increased awareness on sustainability issues in their community and more importantly, how they can contribute to solving these issues as individuals through design.

As such, the current study showed that design education could be a potentially viable approach to achieve the new educational directions for Japanese high school education. The limitation of this study is that the current study can only be a form of initial indicators to present the viability of design education as a critical driver to enhance SDGs awareness and develop 21CC and SEL. As the current programme is still very raw, more substantial theoretical backing to design students' learning is required. As such, detail classroom observations and data collection, monitoring using student design portfolios, applications of formative assessment feedback and teachers' feedback are necessary to provide a more holistic understanding on the capabilities of such design education in the current context. But to create a successful program, more integration into the main school curriculum in terms of the number of hours available for such design programmes needs to be reviewed. For future study, professional training for Japanese high school teachers to run such design programmes are necessary. In addition, the development of teaching and learning materials will be essential to support such design programmes.

\section{CONCLUSIONS}

This study aimed to clarify the used of design education as a form of general education to enhance SDGs awareness and development 21CC and SEL. From this study, design education can be positioned as a form of PBL to integrate into the Japanese high school education that is not structured for design learning. Design education also provides another way of learning for students to engage in solving realworld problems that are different from other subjects. The design activities also allowed high school students to develop 21CC and SEL such as critical thinking, creativity, collaborative and communication skills, and hearing other points of view. As a form of ESD, the current study has the potential to enhance awareness of SDGs and sustainable issues in the local community. But current study needs to consider providing students with sufficient time for more in-depth discussions about issues and solution.

\section{ACKNOWLEDGEMENTS}

The authors would like to extend their appreciation to the principal and teachers of Fukusho High School for this study. This work was supported by JSPS KAKENHI Grant Number JP18K13168. 


\section{REFERENCES}

[1] Cross, N. (1982). Designerly ways of knowing. Design Studies, 3(4), 221-227.

[2] Jonasson, D.H. (1997). Instructional Design Models for Well-Structured and Ill-Structured Problem-Solving Learning Outcomes, Educational Technology Research and Development, 45(1), 65-94.

[3] Jonasson, D.H. (2000). Towards a design theory of problem solving. Educational Technology, Research and Development, 48(4), 63-85.

[4] Marc. De Vries (2018). Technology Education: An international history. In M. J. de Vries (eds.). Handbook of Technology Education (pp.73-84). Springer international handbooks of education.

[5] Chia, S.C., and Tan, S. C. J. (2012). Teaching design \& technology to develop students as persons: A Singapore vision. In PATT Sessions at ITEEA Annual Conference 2012 proceedings, 26 (2), 1-6. Long Beach, CA.

[6] Lin, K. Y., Chang, L. T., Tsai, F. H. and Kao, C. P. (2015). Examining the gaps between teaching and learning in the technology curriculum within Taiwan's 9-year articulated curriculum reform from the perspective of curriculum implementation. International Journal of Technology and Design Education, 25(3), 363-385.

[7] Rasinen, A. (2003). An analysis of the technology education curriculum of six countries. Journal of Technology Education, 15(1), 31-47.

[8] Banks, F. \& Williams, J. (2013). International perspectives on technology education. In G. Owen-Jackson (Eds.), Debates in Design and Technology Education (pp.31-48). London and New York: Routledge.

[9] Wakefield, D. \& Owen-Jackson, G. (2013). Government policies and design and technology education. In G. Owen-Jackson (Eds.), Debates in design and technology education (pp. 7-20). London \& New York: Routledge.

[10] Roberts, P. (2013). The aims of design education. In K. Baynes \& Eddie Norma (Eds.), Design Education: a vision for the future (pp.34-50). UK: Loughborough Design Press Ltd.

[11] Stables, K. (2002). Assessment in design and technology: Authenticity and management issues. In S. Sayers, J. Morley \& B. Barnes (Eds.), Issues in Design and Technology Teaching (pp.129149). London: Routledge Falmer.

[12] Dow, W. (2004). The role of implicit theories in the development of creative classroom. In E. W. L. Norman, D. Spendlove, P. Grover, \& A. Mitchell (Eds.), Data International Research Conference 2004 (pp. 61-66). Wellsbourne: Design and Technology Association.

[13] Feng, W. W., \& Siu, K. W. M. (2009). Meeting the challenges of education of education reform: Curriculum development of technology education in mainland China and Hong Kong. In International conference on technology education in the Asia Pacific Region conference proceedings: Less if more (pp.447-457). Taipei: National Taiwan Normal University.

[14] Middleton, H. (2005). Creative thinking, values and design and technology education. International Journal of Technology and Design Education, 15(1), 61-71.

[15] Rutland, M. \& Barlex, D. (2008). Perspectives on pupil creativity in design and technology in the lower secondary school curriculum in England. International Journal of Technology and Design Education, 18(2), 139-165.

[16] Barak, M. (2018). Teaching and Learning Technology in different domains: tradition and future developments. In M. de Vries (Eds.). Handbook of Technology Education (pp.283-287). Springer international handbooks of education.

[17] Rasinen, A., 43-44.

[18] Fox-Turnbull, W. (2012). Learning in technology. In J. Williams (Eds.) Technology Education for Teachers (pp.55-92). The Netherlands: Sense Publisher

[19] Barak, M., 284

[20] Fox-Turnbull, W., 55-89.

[21] Ibid.

[22] Aaltio, I. \& Heilmann, P. (2010). Case study as a methodological approach. In A. J. Mills, G. Durepos \& E. Wiebe (Eds.), Encyclopaedia of Case Study Research (pp.66-76). California: Sage Publications, Inc

[23] Ibid.

[24] The SDGs Design School in Collaboration with Fukusho High School (2019, Nov 12). https://www.kidnext.design.kyushu-u.ac.jp/projects/3798 [Assessed on 01 March 2020] 